\title{
Study of Determinants of Various Anthropometric Measurements of Neonates at Birth
}

\author{
Chandan Kumar ${ }^{1}$, Ashok Kumar², Abhishek Kumar \\ 1Department of Paediatrics, Darbhanga Medical College and Hospital, Laheriasarai, Bihar, India. \\ ${ }^{2}$ Department of Paediatrics, Darbhanga Medical College and Hospital, Laheriasarai, Bihar, India. \\ ${ }^{3}$ Department of Paediatrics, Darbhanga Medical College and Hospital, Laheriasarai, Bihar, India.
}

\section{ABSTRACT}

\section{BACKGROUND}

Birth weight is considered as one of the most important factors that affect the neonatal mortality in both developing and developed countries. In addition, it is a significant determinant of post neonatal mortality, infant and childhood mortality and morbidity. This study was conducted to evaluate the various factors influencing anthropometric measurements of neonates at birth.

\section{METHODS}

This is a hospital based cross sectional study consisting of neonates and their respective mothers delivered at Darbhanga Medical College, Laheriasarai, Bihar, during the period April 2018 to September 2019. Neonates were divided into three groups $<2500$ gms, 2500-3500 gms, $>3500$ gms and these groups were studied in relation to the determining factors of mothers.

\section{RESULTS}

Among 1000 babies, 56.3\% were male and 43.7\% were female. Mean birth weight was $2596.90 \pm 542.79$ gms ( \pm SD). Mean birth weight was higher in males and LBW rate was higher in males. $37.3 \%$ of babies were LBW babies. Duration of gestation determines birth weight and other anthropometric parameters proportionately increase with birth weight. In the present study, $15.7 \%$ were preterm babies, and $1.8 \%$ of babies were post term babies. Factors like maternal age, weight, pregnancy weight gain, socio economic status, Muslim religion, maternal literacy, birth order ( $2^{\text {nd }}$ onwards), male sex, singleton pregnancy, non-anaemic status, higher period of gestation and spacing had positive correlation with birth weight and negative correlation with LBW incidence. $1 / 3^{\text {rd }}$ of LBW babies were preterm and $2 / 3^{\text {rd }}$ were IUGR babies. In this study, anaemia and diabetes was $79.9 \%$ and $3 \%$ respectively. Maternal diabetes mellitus is an important risk factor for macrosomia.

\section{CONCLUSIONS}

By avoiding teenage pregnancies, adapting family planning methods, providing good quality antenatal care, improving maternal nutrition, spacing of more than three years, correcting anaemia, early recognition of obstetric complications and timely intervention will reduce percentage of LBW babies, increase the mean birth weight and increase the other newborn anthropometric parameters at birth, which will lower the infant mortality and improve the survival.

\section{KEY WORDS}

Anthropometric Measurements, Newborn, Determinants, Birth Weight, Low Birth Weight, Anaemia

\author{
Corresponding Author: \\ Dr. Ashok Kumar, \\ Associate Professor, \\ Department of Paediatrics, \\ Darbhanga Medical College \& Hospital, \\ Laheriasarai, Bihar, India. \\ E-mail:amrit_nursing@yahoo.com
}

DOI: $10.14260 /$ jemds/2020/398

Financial or Other Competing Interests: None.

How to Cite This Article:

Kumar C, Kumar A, Kumar A. Study of determinants of various anthropometric measurements of neonates at birth. J. Evolution Med. Dent. Sci. 2020;9(24):18231826, DOI: $10.14260 /$ jemds/2020/398

Submission 10-02-2020,

Peer Review 05-05-2020,

Acceptance 11-05-2020,

Published 15-06-2020.

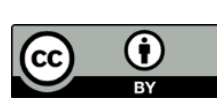




\section{BACKGROUND}

Birth weight of neonates is a good indicator to measure the level of health and health care in different countries. Birth weight and gestational age of a neonates were considered as the most important determinants for the survival, future healthy growth, and overall development of the child. Several factors like maternal, foetal and placental factors determine the birth weight and other anthropometric measurements of neonates at birth. The normal birth weight in our country is 2900 grams. Low birth weight is defined as a birth weight of less than 2500 grams irrespective of gestational age. ${ }^{1}$ The prevalence in India range from $21 \%$ to $33 \% .{ }^{2} \mathrm{LBW}$ either due to being born prematurely or being intrauterine growthretardation.

The weight of an infant at birth is an important predictor of infant growth and survival. Infants born with low birth weight (LBW) are highly vulnerable for childhood infection and under nutrition which have high rates of morbidity and mortality. The low birth weight is considered as sensitive index of nation`s health and development. Over $80 \%$ of all neonatal deaths in developed and developing countries, occur among LBW. ${ }^{1}$ It is estimated that LBW infants have 2.3 times more risk of mortality due to infections compared to normal birth weight infants. In India one third neonates are premature and other two third are IUGR/SGA. LBW neonates have an increased risk of chronic diseases including high blood pressure, non-insulin dependent diabetes mellitus, coronary heart disease and stroke. Low birth weight is an intergenerational problem as these infant grow up to be undernourished adolescents and, ultimately, undernourished women of childbearing age, and undernourished pregnant women who deliver low birth weight infants. This amplifies risks to the individual's health and perpetuates the cycle of poverty under nutrition and disease.

The neurodevelopmental sequelae of birth asphyxia are three times more in LBW babies compared to normal weight babies. The associations between LBW and a greatly elevated risk of infant mortality and other physical and neurological impairments, are well established. Low birth weight is a complex syndrome which can be caused by prematurity, IUGR (intrauterine growth retardation) or both the factors. It has long been recognized maternal age, maternal nutritional status, access to antenatal care, presence of heavy work load, and parental educational status, gestational age, presence of pregnancy related illness, maternal stature and, weight gain during pregnancy are determinant of LBW.

The high incidence of LBW babies in India is due to female literacy, child marriages, teenage pregnancy, lack of ANC, frequent pregnancies, poverty, maternal malnutrition, infections and anaemia. Most of the determinants are preventable and operable in our hands as compared to western countries where preterm out number SGA and asymmetric IUGR due to genetic causes. It is important to recognize the factors determining the birth weight, especially low birth weight and other anthropometric measurements. Small or light mother will produce small baby, small female baby of light mother may grow up to become small girl. Women due to altered growth and exposed to further deleterious effects of poverty, malnutrition during infancy and childhood. They grow up as light and short girls with compromised reproductive efficiency. They would thus perpetuate the cycle of producing small babies. LBW rate is directly related to infant mortality rate. A healthy mother brings forth a healthy baby.

Various factors will determine anthropometric measurements of neonates at birth. Among these birth weight and gestational age are important factors determining survival, future growth and overall development of the child. Therefore, this study is designed to assay the influence of maternal anthropometrics, maternal factors are significant determinants of birth weight and other parameters of neonates.

\section{METHODS}

The proposed study is a hospital based cross sectional study conducted among neonates and their respective mothers who delivered at Darbhanga Medical College, Laheriasarai, Bihar during the period of April 2018 to September 2019. 1,000 subjects who satisfied the inclusion criteria were included for the present study by simple random sampling method. At the time of enrolment an informed written consent was obtained from the parents.

\section{Exclusion Criteria}

1. Neonates with congenital anomalies.

2. Neonates being given intravenous fluids.

Birth weight was be measured by electronic weighing scale with accuracy of \pm 5 grams. Head, chest and mid-arm circumferences was measured by non- stretchable measuring tape. Length of the neonates was measured with infantometer. Maternal height was measured with stadiometer. It was done with the help of an attending female nurse in wards. Information was collected from the relevant documents available in the form of mother's hospital file, previous antenatal check-up cards and investigation reports etc and whenever necessary the information cross checked with nearby relative, The investigation reports which were carried out during antenatal period were collected, like; (1) $\mathrm{Hb} \%$, (2) HIV, (3) VDRL, (4) HBsAg and (5) Urine - albumin, sugar, microscopy.

The maternal, foetal and other factors which determine the weight and other anthropometric parameters was collected in a predetermined proforma. The data collected by the above methods was subjected to statistical analysis and the results was displayed in tabulated form.

The socioeconomic classification used in the study is Modified Kuppuswamy classification 2007. ${ }^{3}$ The cut off point for the diagnosis of anaemia for adult pregnant women taken in this study is $11 \mathrm{gm} / \mathrm{dL} .^{3}$ Maternal height of less than $145 \mathrm{~cm}$ is grouped as short mother. ${ }^{1}$ ANC status of the mother is divided into at least 2 doses of TT, minimum 4 ANC visits as booked cases and less than that are unbooked cases.

The obstetric complications, which influence the birth weight under study, were gestational diabetes mellitus and PIH.

Chronic systemic illnesses which affect the birth weight were like congenital/ rheumatic heart disease, genital tract infection and urinary tract infection and were studied. 


\section{Statistical Analysis}

Chi-square test for discontinuous variables and unpaired t-test for continuous variable at $5 \%$ significance $(p<.05)$ level were used for statistical analysis.

\section{RESULTS}

In present study $56.3 \%$ were male and $43.7 \%$ were female babies. Overall Mean birth weight was $2596.90 \pm 542.79 \mathrm{gm} \mathrm{(}$ \pm SD). Mean birth weight was higher in males and LBW rate was higher in males. $37.3 \%$ of babies were LBW babies. Duration of gestation determines birth weight and other anthropometric parameters proportionately increase with birth weight. In the present study $15.7 \%$ were preterm babies, and $1.8 \%$ of babies were post term babies.

\begin{tabular}{|c|c|c|}
\hline Sex of Newborn & Number (\%) & Mean Birth Weight \pm SD (gm) \\
\hline Male & $563(56.3)$ & $2642.32 \pm 554.95$ \\
\hline Female & 437 (43.7) & $2596.39 \pm 521.53$ \\
\hline Total & $1000(100)$ & $2596.90 \pm 542.79$ \\
\hline \multicolumn{3}{|c|}{$\begin{array}{l}\text { Table 1. Distribution of Newborns According } \\
\text { to Gender and Birth Weight }\end{array}$} \\
\hline
\end{tabular}

\begin{tabular}{|cccc|}
\hline & Pre-Term & Term & Post-Term \\
\hline Number (\%) & $157(15.7)$ & $825(82.50)$ & $18(1.8)$ \\
\hline Table 2. Distribution of Newborns & According to Duration of Gestation \\
\hline $\mathrm{p}<.0001 ;$ significant, $\mathrm{n}-1000$ & \\
\hline
\end{tabular}

\begin{tabular}{|c|c|c|c|c|c|c|}
\hline $\begin{array}{c}\text { Maternal } \\
\text { Age } \\
\text { (Year) }\end{array}$ & $\begin{array}{c}<2499 \\
\text { gm } \\
\text { n (\%) }\end{array}$ & $\begin{array}{c}2500- \\
3500 \mathrm{gm} \\
\text { n (\%) }\end{array}$ & $\begin{array}{c}>3500 \\
\text { gm } \\
n(\%)\end{array}$ & $\begin{array}{c}\text { Total } \\
\mathbf{n} \\
(\%)\end{array}$ & $\begin{array}{l}\text { Mean Birth } \\
\text { Weight } \pm \text { SD } \\
\text { (gm) }\end{array}$ & \\
\hline$<20$ & $\begin{array}{c}153 \\
(44.21)\end{array}$ & $\begin{array}{c}191 \\
(55.20)\end{array}$ & $\begin{array}{c}02 \\
(0.59)\end{array}$ & $\begin{array}{c}346 \\
(100)\end{array}$ & $\begin{array}{c}2506.34 \pm \\
525.69\end{array}$ & $\begin{array}{c}\mathrm{p} \\
<.0001\end{array}$ \\
\hline $20-30$ & $\begin{array}{c}208 \\
(33.93)\end{array}$ & $\begin{array}{c}377 \\
(61.500)\end{array}$ & $\begin{array}{c}28 \\
(4.57)\end{array}$ & $\begin{array}{c}613 \\
(100)\end{array}$ & $\begin{array}{c}2622.85 \pm \\
529.02\end{array}$ & \\
\hline$>30$ & $\begin{array}{c}12 \\
(29.26)\end{array}$ & $\begin{array}{c}21 \\
(51.23)\end{array}$ & $\begin{array}{c}08 \\
(19.51)\end{array}$ & $\begin{array}{c}41 \\
(100)\end{array}$ & $\begin{array}{c}2973.17 \pm \\
682.88\end{array}$ & \\
\hline Maternal & Height (cm & & & & & \\
\hline$<145$ & $\begin{array}{c}57 \\
(67.06)\end{array}$ & $\begin{array}{c}28 \\
(32.94)\end{array}$ & $\begin{array}{c}00 \\
(00)\end{array}$ & $\begin{array}{c}85 \\
(100)\end{array}$ & $\begin{array}{c}1953.71 \pm \\
477.01\end{array}$ & $\begin{array}{c}\mathrm{p} \\
<.0001\end{array}$ \\
\hline$\geq 145$ & $\begin{array}{c}316 \\
(34.54) \\
\end{array}$ & $\begin{array}{c}561 \\
(61.31) \\
\end{array}$ & $\begin{array}{c}38 \\
(4.15) \\
\end{array}$ & $\begin{array}{c}915 \\
(100)\end{array}$ & $\begin{array}{c}2656.65 \pm \\
508.98 \\
\end{array}$ & \\
\hline
\end{tabular}

Table 3. Maternal Factors in Relation to Birth Weight of the Babies

\begin{tabular}{|c|c|c|c|c|c|c|}
\hline $\begin{array}{c}\text { Maternal } \\
\text { Factors }\end{array}$ & $\begin{array}{c}<2499 \mathrm{gm} \\
\text { n (\%) }\end{array}$ & $\begin{array}{c}2500- \\
3500 \\
\text { gm n (\%) }\end{array}$ & $\begin{array}{c}>3500 \\
\text { gm } \\
\text { n }(\%)\end{array}$ & $\begin{array}{l}\text { Total } \\
\text { n (\%) }\end{array}$ & $\begin{array}{l}\text { Mean birth } \\
\text { Weight } \pm \text { SD } \\
\text { (gm) }\end{array}$ & \\
\hline Sedentary & $367(37.49)$ & $574(58.63)$ & $38(3.88)$ & $979(100)$ & $2595.23 \pm 546.71$ & $\mathrm{p}<.402$ \\
\hline $\begin{array}{l}\text { Working } \\
\text { women }\end{array}$ & $06(28.57)$ & $15(71.43)$ & $00(00)$ & $21(100)$ & $2674.76 \pm 306.44$ & \\
\hline Maternal & literacy & & & & & \\
\hline Illiterate & $49(53.85)$ & $41(45.05)$ & $01(1.10)$ & $91(100)$ & $2362.97 \pm 597.83$ & \\
\hline $\begin{array}{l}\text { primary } \\
\text { education }\end{array}$ & $20(39.22)$ & $30(58.82)$ & $01(1.96)$ & $51(100)$ & $2537.65 \pm 559.17$ & $\mathrm{p}<.0001$ \\
\hline $\begin{array}{l}\text { Higher } \\
\text { primary }\end{array}$ & $158(38.92)$ & $235(57.88)$ & $13(3.20)$ & $06(100)$ & $2595.53 \pm 516.562$ & \\
\hline High school & $54(37.50)$ & $82(56.94)$ & $08(5.56)$ & $144(100)$ & $2628.85 \pm 580.57$ & \\
\hline $\begin{array}{c}\text { PUC/ } \\
\text { Diploma }\end{array}$ & 81(31.27) & $172(66.41)$ & $06(2.32)$ & $259(100)$ & $2643.67 \pm 482.12$ & \\
\hline Degree & $11(22.45)$ & $29(59.18)$ & $09(18.36)$ & $49(100)$ & $2763.27 \pm 693.11$ & \\
\hline SES & & & & & & \\
\hline I & $00(00)$ & $00(00)$ & $00(00)$ & $00(00)$ & - & \\
\hline II & $06(15.79)$ & $28(73.68)$ & $04(10.53)$ & $38(100)$ & $2803.42 \pm 555.06$ & $\mathrm{p}<.0001$ \\
\hline III & $69(36.5$ & $102(53.97)$ & $18(9.52)$ & $89(100)$ & $2700.19 \pm 572.45$ & \\
\hline IV & $270(37.14)$ & $442(60.80)$ & $15(2.06)$ & $727(100)$ & $2581.54 \pm 519.48$ & \\
\hline $\mathrm{V}$ & $28(60.87)$ & $17(36.96)$ & 01(2.17) & $46(100)$ & $2244.67 \pm 594.18$ & \\
\hline Weight & Gain & During & \multicolumn{2}{|c|}{ Pregnancy } & & \\
\hline$<7$ & $154(78.98)$ & $41(21.02)$ & $00(00)$ & 195(00) & $1895.97 \pm 394.06$ & $\mathrm{p}<.0001$ \\
\hline $7-8.9$ & $86(46.24)$ & $94(50.54)$ & $06(3.22)$ & $186(100)$ & $2392.47 \pm 321.139$ & \\
\hline $9-10.9$ & $75(28.52)$ & $176(66.92)$ & $12(4.56)$ & $263(100)$ & $2643.37 \pm 293.86$ & \\
\hline$>11$ & $58(16.30)$ & $278(78.08)$ & $20(5.62)$ & $356(100)$ & $3053.31 \pm 542.79$ & \\
\hline
\end{tabular}

Factors like maternal age, weight, pregnancy weight gain, socio economic status, Muslim religion, maternal literacy, birth order of $2^{\text {nd }}$ onwards, male sex, singleton pregnancy, nonanaemic status, higher period of gestation and spacing has got positive correlation with birth weight and negative correlation with LBW incidence. $1 / 3^{\text {rd }}$ of LBW babies were preterm and $2 / 3^{\text {rd }}$ were IUGR babies. In this study anaemic and diabetes was $79.9 \%$ and $3 \%$ respectively. Maternal diabetes mellitus is an important risk factor for macrosomia.

\begin{tabular}{|c|c|c|c|c|c|c|}
\hline $\begin{array}{c}\text { Inter } \\
\text { Pregnancy } \\
\text { Interval } \\
\text { (Year) }\end{array}$ & $\begin{array}{c}<2499 \\
\text { gm } \\
\text { n }(\%)\end{array}$ & $\begin{array}{c}2500- \\
3500 \\
\text { gm } \\
\text { n (\%) }\end{array}$ & $\begin{array}{c}>3500 \\
\text { gm } \\
\text { n (\%) }\end{array}$ & $\begin{array}{c}\text { Total } \\
\mathbf{n} \\
(\%)\end{array}$ & $\begin{array}{c}\text { Mean Birth } \\
\text { Weight } \pm \text { SD } \\
\text { (gm) }\end{array}$ & \\
\hline$<1$ & $36(40.00)$ & $53(58.89)$ & 01(1.11) & $90(100)$ & $2481.33 \pm 621.22$ & $\begin{array}{c}P \\
<.0001\end{array}$ \\
\hline $1-1.5$ & $38(37.26)$ & 63 (61.76) & $01(0.98)$ & $102(100)$ & $2580.78 \pm 484.86$ & \\
\hline & & & 03 & & & \\
\hline 2.1 & & & & & & \\
\hline & & & & & & \\
\hline$>3$ & 03(11.54) & $12(46.15)$ & $11(42.31)$ & $26(100)$ & $3113.27 \pm 692.87$ & \\
\hline Birth & Order & & & & & $\begin{array}{c}\mathrm{p} \\
<.0001\end{array}$ \\
\hline I & & & & & & \\
\hline II & & & $21(8$. & & & \\
\hline & & & & & & \\
\hline IV and above & ( $19(36.54)$ & $30(57.69)$ & $03(5.77)$ & $52(100)$ & $30003.27 \pm 487.08$ & \\
\hline Non-diabetes & & $571(58.87)$ & $26(2.68)$ & $970(100)$ & $2573.33 \pm 530.82$ & $\begin{array}{c}\mathrm{p} \\
<.0001\end{array}$ \\
\hline Diabetes & $00(00)$ & $18(60.00)$ & $12(40.00)$ & $30(100)$ & $3359.00 \pm 338.55$ & \\
\hline Anaemic & $320(40.05)$ & $461(57.70)$ & $18(2.25)$ & $799(100)$ & $2542.88 \pm 518.74$ & $\begin{array}{c}\mathrm{p} \\
<.0001\end{array}$ \\
\hline Non-anaemic & $53(26.37)$ & $128(63.68)$ & $20(9.95)$ & $201(100)$ & $2811.64 \pm 583.03$ & \\
\hline
\end{tabular}

\section{DISCUSSION}

In the present study there were randomly selected 1,000 neonates born at Darbhanga medical college, Laheriasarai, Bihar and their respective mothers, during the period April 2018 to September 2019. There were 563 (56.3\%) male babies and $437(43.7 \%)$ female babies. Comparable ratio of male and female babies was observed $58.18 \%$ male, $41.82 \%$ female by Bansal, et al $^{4}$ and $51.33 \%$ male, $48.76 \%$ by Motwani NP et al ${ }^{5}$. Mean birth weight of male $2642.32 \pm 554.95 \mathrm{gm}( \pm$ SD) and female $2596.39 \pm 521.53 \mathrm{gm}( \pm \mathrm{SD})$. Male baby were heavier than female. Similar observation were made in Samiran BiSai6. Where male babies mean weight 2642.32 gm and female babies mean weight $2538.39 \mathrm{gm}$. Incidence of pre-term births in present study was $15.7 \%$, term births was $82.5 \%$ and Postterm births was $1.8 \%$. Similar observation $20.90 \%$ pre-term, $79.1 \%$ post-term, by Bansal, et $\mathrm{al}^{4}$. In India 10 to 12 percent of babies born pre-term ${ }^{2}$ as compared to 5 to 7 percent in the West.

Mean birth weight is $2506.34 \pm 525.69 \mathrm{gm}( \pm \mathrm{SD})$, lowest in mothers less than 20 years which may be due to physiological immaturity and under nutrition and $2068 \pm$ $223.99 \mathrm{gm}( \pm \mathrm{SD})$ in $<20$ years, $2719.91 \pm 437.02 \mathrm{gm}( \pm \mathrm{SD})$ in 20-30 years, $2932.78 \pm 429.99 \mathrm{gm}( \pm$ SD) in $>30$ years by Motwani NP et $\mathrm{al}^{5}$. As the maternal age increases birth weight increases. Maternal height of less than $145 \mathrm{~cm}$ is grouped as short mother ${ }^{1}$. The mean birth weight was $1953.71 \mathrm{gm}$ lowest in maternal age group with less than $145 \mathrm{~cm}$ and mean birth weight increases as the maternal height increases and Present study is comparable to study observed $2794 \mathrm{gm}$ in maternal height $<145 \mathrm{~cm}$ by Raman L. ${ }^{7}$ 
In the present study 21 working women were recorded and remaining 979 were housewives. Mean birth weight in working group was $2674.76 \pm 306.44 \mathrm{gm}$ ( \pm SD) compared to sedentary group, $2595.23 \pm 546.71 \mathrm{gm}( \pm$ SD). Minimum physical work is must for better outcome. Mean birth weight was lowest in illiterates and it increases as the maternal literacy increases and highest in mothers who have completed degree. According to socio economic status (Modified Kuppuswamy classification 2007) ${ }^{3} .2244 .67 \pm 594.18$ gm ( \pm SD) lowest in class V socio economic status, $2581.54 \pm 519.48$ gm ( \pm SD) in class IV, $2700.19 \pm 572.45 \mathrm{gm}( \pm$ SD) in class III, and $2803.42 \pm 555.06 \mathrm{gm}( \pm \mathrm{SD})$ in class II. Birth weight increases in upper socio economic status. compare to Raman L7. were $2879 \mathrm{gm}$ in class II, $2832 \mathrm{gm}$ in class III, $2726 \mathrm{gm}$ in class IV.

Mean birth weight increases with increase in maternal weight gain during pregnancy. Mean birth weight was 1895.97 $\pm 394.06 \mathrm{gm}( \pm \mathrm{SD}$ ) in pregnancy weight gain less than $7 \mathrm{kgs}$. compare to Motwani NP et al ${ }^{5}$. Where $2465.22 \pm 500.1$ gm ( \pm SD) in pregnancy weight gain less than 7 kgs. Mean birth weight was lowest in $<1$ year Inter pregnancy interval group, increases as the s Inter pregnancy interval increases.

Mean birth weight was low in Birth order I group, increases in II, III, IVth and above birth order. Similar trend observed in studies done by. Prasad KN ${ }^{8} 1994$ and Shajari H. ${ }^{9}$ The cut off point for the diagnosis of anaemia for adult pregnant women taken in this study is $11 \mathrm{gm} / \mathrm{dL} .^{3}$ Mean birth weight in anaemic group was $2542.88 \pm 518.74 \mathrm{gm}( \pm$ SD) and non-anaemic group was $2811.64 \pm 583.03 \mathrm{gm}( \pm \mathrm{SD})$ with 268 gm higher mean birth weight. Comparable observed in the study conducted by S. Swain et al ${ }^{10} 2662$ gm in anaemic group and $2846 \mathrm{gm}$ in non-anaemic group.

In present study $30(3.0 \%)$ babies with maternal diabetes mellitus. Mean birth weight was $3359.00 \pm 338.55$ gm ( \pm SD) in diabetic group compared to $2573.33 \pm 530.82 \mathrm{gm}( \pm$ SD) in non-diabetic group, which is lower than by $785.67 \mathrm{gm}$. comparable trend was observed in the studies done by Vedavathi.et al. ${ }^{11}$ Kevin Johns et al. ${ }^{12}$

\section{CONCLUSIONS}

Foetal growth depends on duration of gestation and uptake of nutrients from mother through placenta. Uptake of nutrients depends on many factors like nutritional status of mother, dietary intake during pregnancy, utilization and absorption in the mother and genetic constitution of foetus. Nutritional factors are also likely to influence placental function including vascular structure and efficiency of placental transport.
Many factors influence birth weight. Some of the factors are modifiable like age at conception, weight gain during pregnancy, pre-pregnancy weight, anaemic status etc., and some factors are not modifiable like, sex of the baby, birth order, religion etc. Hence it is important to assess the influence of these modifiable factors on pregnancy and its outcome.

\section{REFERENCES}

[1] Singh M. Care of the new born. Revised $8^{\text {th }}$ edn. New Delhi: CBS Publication \& Distrubutors Pvt. Ltd., 2017: p. 301-22.

[2] Parthasarathy A, Menon PSN, Nair MKC. IAP text book of Pediatrics. $7^{\text {th }}$ edn. New Delhi: Jaypee Brother Medical Publishers (P) Ltd., 2019: p. 46, 53.

[3] Park K. Park's Textbook of Preventive and social medicine. 25st edn. Jabalpur: M/s Banarsidas Bhanot Publishers 2019: p. 619, 622, 680.

[4] Bansal P, Garg S, Upadhyay HP, et al. Prevalence of low birth weight babies and its association with socio-cultural and maternal risk factors among the institutional deliveries in Bharatpur, Nepal. Asian Journal of Medical Science 2019;10(1):77-85.

[5] Motwani NP et al. Effect of maternal age and gestational weight gain on anthropometry of the newborn in semi urban area of Chhattisgarh, India. Int J Contemp Pediatr:2019 Nov;6(6):2374-2378.

[6] Bisai S, Sen A, Mahalanabis D, et al. The effect of maternal age and parity on birth weight among Bengalees of Kolkata, India. Human Ecology Special Issue 2006;14:139-43.

[7] Raman L. Influence of maternal nutritional factors affecting birth weight. American Journal of Clinical Nutrition 1981;34(Suppl 4):775-83.

[8] Prasad KN, Rao RS, Sujatha A. Birth weight pattern in Karnataka. Indian Paediatrics 1994;31(7):836-9.

[9] Shajari H, Marsoosy V, Aslani M, et al. The effect of maternal age, gestational age and parity on the size of the new born. Acta Medica Iranica 2006;44(6):400-4.

[10] Swain S, Singh S, Bhatiya BD, et al. Maternal haemoglobin and serum albumin and foetal growth. Indian Pediatrics 1994;31(7):777-82.

[11] Vedavathi KJ, Swamy RM, Kanavi RS, et al. Influence of gestational diabetes mellitus on foetal growth parameters. Int J Biol Med Res 2011;2(3):832-4.

[12] Johns K, Olynik C, Mare R, et al. Gestational diabetes mellitus outcome in 394 patients. J Obstet \& Gynaecol Can 2006;28(2):122-7. 